\title{
Biopharmaceutics classification system: importance and inclusion in biowaiver guidance
}

\author{
Lorena Barbosa Arrunátegui, Neila Márcia Silva-Barcellos, Karime Rezende Bellavinha, \\ Lisiane da Silveira Ev, Jacqueline de Souza*
}

Universidade Federal de Ouro Preto, Escola de Farmácia, Departamento de Farmácia, Ouro Preto, MG, Brazil

Pharmacological therapy is essential in many diseases treatment and it is important that the medicine policy is intended to offering safe and effective treatment with affordable price to the population. One way to achieve this is through biowaiver, defined as the replacement of in vivo bioequivalence studies by in vitro studies. For biowaiver of new immediate release solid oral dosage forms, data such as intestinal permeability and solubility of the drug are required, as well as the product dissolution. The Biopharmaceutics Classification System (BCS) is a scientific scheme that divides drugs according to their solubility and permeability and has been used by various guides as a criterion for biowaiver. This paper evaluates biowaiver application, addressing the general concepts and parameters used by BCS, making a historical account of its use, the requirements pertaining to the current legislation, the benefits and risks associated with this decision. The results revealed that the use of BCS as a biowaiver criterion greatly expands the therapeutics options, contributing to greater therapy access of the general population with drug efficacy and safety guaranteed associated to low cost.

Uniterms: Medicines/biowaiver. Biopharmaceutics Classification System. Drugs/solubility. Drugs/ permeability. Drugs/dissolution. Drugs/legislation.

O tratamento farmacológico é essencial frente a várias patologias e é fundamental que a política de medicamentos tenha por objetivo oferecer à população tratamento seguro, eficaz e de preço acessível. Uma forma de alcançar esse objetivo é por meio da bioisenção, definida como a substituição de estudos de bioequivalência in vivo por estudos in vitro. Para bioisentar novos medicamentos sob a forma farmacêutica sólida oral de liberação imediata são utilizados dados de permeabilidade intestinal e solubilidade do fármaco, bem como sua dissolução a partir da forma farmacêutica. O Sistema de Classificação Biofarmacêutica (SCG) é um esquema científico que divide os fármacos em classes de acordo com solubilidade e permeabilidade e vem sendo utilizado como critério para bioisenção em diversas legislações. O presente artigo faz uma avaliação desta utilização, abordando os conceitos gerais e parâmetros utilizados pelo SCB, fazendo um relato histórico da aplicação da bioisenção, das exigências pertinentes às legislações vigentes, dos benefícios e riscos inerentes a uma tomada de decisão sobre bioisenção baseada neste critério. Os resultados revelaram que a utilização do SCB como critério amplia enormemente as possibilidades de bioisenção, contribuindo para o maior acesso da população em geral a medicamentos com garantida eficácia, segurança e menor custo.

Unitermos: Medicamentos/bioisenção. Sistema de Classificação Biofarmacêutica. Fármaco/solubilidade. Fármaco/permeabilidade. Fármaco/dissolução. Fármaco/legislação.

*Correspondence: J. Souza. Laboratório de Controle de Qualidade - CiPharma, Escola de Farmácia Campus do Morro do Cruzeiro, 35400-000 - Ouro Preto MG, Brasil. E-mail: jacsouza@ef.ufop.br 


\section{INTRODUCTION}

Medicines are the most important tool that society possesses to prevent, alleviate and cure diseases (Leach, Palluzi, Munderi, 2005). However, about $30 \%$ of the world population has no access to effective, safe and quality medicines, and more than half of those live in developing countries in Africa and Asia (WHO, 2004). This problem is so serious that in 2000 the United Nations (UN), analyzing the major problems of the world, established the Millennium Program, where 191 countries signed an agreement with 8 goals and 18 targets that must be achieved until 2015. One of these goals is to provide access to quality essential medicines at affordable prices (Brasil, 2007).

Several factors influence people's access to medicines and it is necessary a national policy to regulate and monitor these several factors. Among those we may cite: a system for efficient drug selection and free from pressures, a policy of public funded sustainable system for regulating the drug market, controlling overtaxes and other factors that impact on prices, as well as an efficient distribution system (Leach, Palluzi, Munderi, 2005).

In this sense, the policy of generic medicines is an important strategy for increasing access to essential medicines, particularly in developing countries by reducing costs, both for the consumer as for purchase by the public system, for subsequent distribution to the population.

Some defined dosage forms of generic medicines must necessarily prove its bioequivalence in relation to the reference product (Miranda et al., 2009). This testing assess the intensity and extent of absorption in humans and to do this, the costs are high, inherent to the clinical, analytical and statistical steps that consume the time of 3 to 7 months between the selection of which center will elaborate the studies, approval by the ethics committee on research, development and selection of volunteers for those steps. However, this provides consumers with the opportunity to purchase medicines at more affordable prices, with a guarantee of quality, safety, efficiency and interchangeability with the reference medicines (Araújo et al., 2010; Melo, 2005).

The Food and Drug Administration (FDA), the U.S. regulatory agency, estimates that in coming years, US\$ 60 to US\$ 70 billion in branded medicines will lose their patent protection (United States, 2007). This means that these drugs may be considered to be registered as generic, but for this, it is necessary knowledge and structure able to respond quickly to a potential increase in demand for generic drugs registration. In order to do that, biowaiver can be a good tool and thus bring benefits to the society by expanding the supply of medicines effective with guaranteed security. The biowaiver can be defined as the acceptance for regulatory purposes, of the exemption or replacement of in vivo bioequivalence studies and bioavailability by in vitro assays when they are able to replace the in vivo assay reliably (Storpirtis, Gai, 2009). The registration process through biowaiver enables a reduction in the exposure of volunteers in clinical studies, time and cost of product development with quality and safety certified (Lennernäs, Abrahamsson, 2005). Therefore, the biowaiver brings considerable benefits for the patient and government health systems. In Brazil, it is an important contribution to the national health system (SUS) in terms of access to drug treatment. The Food and Drug Administration and Agência Nacional de Vigilância Sanitária (ANVISA) that is the Brazilian regulatory agency, use the Biopharmaceutics Classification System (BCS) as a mean to allow biowaiver of ImmediateRelease Solid Oral Dosage Forms containing drugs with high solubility and permeability (BCS Class I) (United States, 2000 Brasil, 2011). The European Union agency (EMA) responsible to indicate candidates to biowaiver has considered eligible the class I of BCS and additionally, drugs which have high solubility and low permeability (BCS Class III), when they show very rapid dissolving ( $85 \%$ in 15 minutes). The World Health Organization (WHO) further extends the applicability of biowaiver for drugs in classes I, III and also drugs poorly soluble and highly permeable (Class II), when they have characteristics of weak acid and high solubility in $\mathrm{pH} 6,8$, besides rapid or very rapid dissolving (EMEA, 2008; WHO, 2006).

This article aims to contribute to the understanding of the general concepts on the topic and discuss the inclusion of BCS as a biowaiver criterion. Moreover, it presents the historical account of the relevant legislation, effective criteria to apply biowaiver and discusses the benefits and risks of using the BCS as a regulatory tool.

\section{METHODS}

The laws related to biowaiver were checked at sites of the regulatory agencies of interest, ANVISA (http:// www.anvisa.gov.br/e-legis), FDA (http://www.fda.gov/ default.htm) and EMA (http://www.ema.europa.eu/ema/), to evaluate the inclusion of BCS as a criterion to enable biowaiver. Additionally, we carried out search of scientific basis for allowing the presentation and discussion of the laws cited. With this goal bibliographic data bases 
PubMed (www.ncbi.nlm.nih.gov), Scopus (www.scopus. com/home.url) and SciELO (www.scielo.org) were consulted from November 2011 to February 2014, using the following search terms: biowaiver, BCS, permeability and solubility.

\section{THEORETICAL BASIS FOR BIOWAIVER}

\section{Biopharmaceutical classification system}

The Biopharmaceutical Classification System is a scientific schematic proposed by Amidon and coworkers in 1995, which allowed the classification of drugs based on solubility and intestinal permeability parameters in four classes (Amidon et al., 1995).

The four possible categories for a drug according to the BCS are in Table I

TABLE I -The Biopharmaceutical Classification System scientific framework

\begin{tabular}{ccc}
\hline Class & Solubility & Permeability \\
\hline I & High & High \\
II & Low & High \\
III & High & Low \\
IV & Low & Low \\
\hline
\end{tabular}

The solubility and intestinal permeability are among the main factors that govern the rate and extent of drug absorption and therefore are directly related to bioavailability (Amidon et al., 1995).

The insertion of the BCS as a criterion for biowaiver started in FDA guide, also being currently accepted by ANVISA and EMA. This addition allowed the simplification of registration of new medicines according to Abbreviated New Drug Application (ANDA) in USA (Löbenberg, Amidon, 2000).

\section{Solubility}

By definition, solubility is the extent to which one molecule of a solid is removed from its surface by a solvent (Martinez, Amidon, 2002) being a determining factor for the absorption and bioavailability of active compounds (Panchagnula, Thomas, 2000).

A drug is considered highly soluble when the highest dose administered as an immediate release formulation, is soluble in $250 \mathrm{ml}$ or less of aqueous media with a $\mathrm{pH}$ in a range of 1.2 to 6.8 at $37 \pm 1{ }^{\circ} \mathrm{C}$ (Brasil, 2011).

\section{Permeability}

The permeability is a dynamic and complex process that involves the permeation of the drug across biological membranes. The arrival of the drug into the bloodstream is made by the absorption pharmacokinetics processes. The transport mechanisms include passive diffusion through the enterocytes (transcellular) and the junctions between the enterocytes (paracellular) as well as active mechanisms employing energy and carriers (Balimane et al., 2000).

A drug is considered highly permeable when the extent of absorption in humans is $85 \%$ (Brasil, 2011; EMEA, 2008; WHO, 2006) or more, based on mass balance determination or in comparison with an intravenous dose. On the other hand, according to FDA (2000) one drug is classified as highly permeable when the fraction of the absorbed dose or the absolute bioavailability is equal or greater than $90 \%$. This criterion can be considered conservative because there are many reports of drugs that are generally considered well or completely absorbed, that present fraction of absorbed dose less than $90 \%$. This suggests that a threshold rating of $85 \%$ may be appropriate in the definition of high permeability (Yu et al., 2002).

The need to obtain data relating to intestinal permeability of drugs has raised the development of various models for the determination of permeability, which may be in vivo, in situ, in vitro and in silico (Souza, Freitas, Storpirtis, 2007). The methods continue to be improved and it is recommended that conclusions should be obtained by using more than one method (Balimane et al., 2000).

\section{Dissolution}

The dissolution can be defined in a narrow sense as the process by which a solid substance enters the solvent to form a solution. However, in the broad sense of the word, it is more than simply measuring the rate of solubility and can be more correctly described as a physical assay to predict the release of substance for a given area, in quantity and adequate time (Manadas, Pina, Veiga, 2002).

The absorption of a drug contained in solid dosage form after oral administration depends on its release, solubilization and dissolution under physiological conditions and posterior permeability through the gastrointestinal tract. The first two steps present a critical nature and therefore, in vitro dissolution may be relevant to predict the in vivo performance. In vitro dissolution tests for oral solid dosage forms such as tablets and capsules are used to: [1] assess the quality of a batch to batch drug; [2] guide development of new formulations; 
[3] guarantee the maintenance of product quality after certain changes in the design, process, and on site production scale (United States, 1997) and [4] assess the pharmaceutical equivalence between products from different manufacturers (Rodrigues et al., 2006).

One way to evaluate the dissolution is by determining the dissolution profile, graph of percentage of drug dissolved versus time, which is a relatively quick and inexpensive way to evaluate solid dosage forms and allows obtaining kinetic parameters. These are important for determining the speed and efficiency of the process and the time needed for specific release of drug percentages, allowing conclusions about in vitro biopharmaceutical characteristics of the formulation (Storpirtis et al., 1999).

\section{Pharmaceutical Equivalence}

Pharmaceutical equivalence between two medicines is related to the confirmation that both contain the same drug (same basis, salt or ester of the same therapeutically active molecule) at the same dose and dosage form, and may be evaluated through in vitro tests (Storpirtis et al., 2004). To be considered pharmaceutical equivalents, the test and reference medicine must comply in full with the requirements of pharmacopoeia monographs, completed with assays described in general methods for the pharmaceutical form (Brasil, 2010).

\section{Bioequivalence/Relative Bioavailability}

Bioequivalence or relative bioavailability is the comparative study of products containing the same drug administered by the same route. Two products are considered bioequivalent if, when administered to the same individual under the same experimental conditions and at the same molar dose do not differ significantly from the amount of drug absorbed and the rate of absorption process (Storpirtis, Consiglieri, 1995).

Brazilian law states that for a drug to be registered as generic, it is necessary to prove their pharmaceutical equivalence and bioequivalence in respect to the reference product indicated by ANVISA (Brasil, 2003a). As for similar drugs products, it is required to prove pharmaceutical equivalence and similar relative bioavailability to the inclusion of a new product or renewal of registration of drugs already on the market (Brasil, 2003b).

For the registration of similar medicines in Brazil, up to the year 2003, it was not necessary the proof of bioavailability. According to RDC N.134/2003 the new reality of achieving this requirement must occur until 2014. For this process, ANVISA adopted "Relative bioavailability" for similar medicines as a term to differentiate them from generic medicines (interchangeable), since the term "bioequivalence" is established and accepted internationally for generic products (Araújo et al., 2010).

\section{BIOWAIVER}

A Biowaiver means that relative bioavailability and/ or bioequivalence tests are not required for the registration of a medicine by the regulatory authority, when a suitable in vitro assay can replace it (Brasil, 2011).

The main reason for biowaiver based on the BCS is that in some situations, in vitro assays are as good as in vivo tests to determine the bioequivalence of oral solid dosage forms and sometimes better in terms of direct evaluation of product performance. Moreover, biowaiver eliminates unnecessary exposure of healthy subjects to in vivo studies, reduces the burden of evaluating petitions for registration requiring BE studies, and provides economic relief, maintaining the quality standard of dispensed medicines to public health and thus ensuring therapeutic equivalence (Cook et al., 2010).

An estimated 66 to 76 million dollars can be saved each year in costs of clinical studies if biowaiver is granted to all applications for new drugs containing drug class I. If this is extended to class III compounds, additional savings from 62 to 71 million dollars can be performed (Cook et al., 2010).

\section{BCS AS BIOWAIVER CRITERION}

The first legislation of biowaiver which includes the $\mathrm{BCS}$ as a criterion and that is still in use, was published by the FDA in August 2000. This exemption would be based on the grounds that, if two formulations present the same dissolution profile in vivo, under the same conditions of the intestinal lumen, they present the same profile of concentration versus time on the surface of the intestinal membrane, which results in the same rate and extent of absorption (United States, 2000).

ANVISA, as well as FDA, in its recently published guide, RDC Resolution No. 37, August 3, 2011 (Brazil, 2011), recommends the exemption of bioavailability/ bioequivalence studies in cases of drugs highly soluble and highly permeable (Class I) into oral solid dosage forms that provide rapid dissolving, in other words, not less than $85 \%$ in 30 minutes. Moreover, evidence of solubility, permeability and dissolution should be performed according to the methods proposed in the legislation 
(United States, 2007; Brasil, 2011).The normative statement (IN) No.2, (ANVISA, 2013) is a document that refers to a list of drugs whose biopharmaceutical characteristics were established and are suitable to pass by the biowaiver process according to RDC Resolution No. 37, August 3, 2011.

In Europe, the EMA published in 2001 its biowaiver guide, which was updated in 2008. In this resolution, FDA and ANVISA recommend the BCS biowaiver in similar way, i.e. for medicines containing drugs class I. Besides these, EMA also considers the biowaiver based on the BCS for class III drugs, i.e. the medicines which have high solubility and limited absorption and also have very fast in vitro dissolution characteristics ( $85 \%$ in 15 minutes), excipients qualitatively and quantitatively identical (EMEA, 2008; EMEA, 2001).

In 2006, the World Health Organization (WHO) published a document entitled "WHO Technical Report Series No. 937" that has an attachment about biowaiver theme ("Proposal to waive in vivo bioequivalence requirements for WHO Model List of Essential Medicines immediate-release, solid oral dosage forms", Annex 8 ). This guide recommends criteria of biowaiver based on BCS, however, its requirements are less stringent than those set by the guides of the FDA, ANVISA and EMA, including drugs of class II, low solubility and high permeability, as liable to biowaiver (when they have characteristics of weak acid and high solubility in $\mathrm{pH}$ 6,8 , besides rapid or very rapid dissolving). The WHO recommendation is to establish less conservative criteria, especially for well-known drugs, such as those that are part of the List of Essential Medicines (WHO, 2006).

In short, according to present guides, for a drug to have its biowaiver accepted, it must have its biopharmaceutical classification proven, according to the criteria of solubility and permeability, as well as dissolution characteristics from the dosage form. Table II has a comparison of the main requirements for obtaining biowaiver based on the BCS, according to regulatory agencies ANVISA, FDA, EMA and WHO. In addition, to meet these criteria, an analysis of the formulation of the biowaiver candidate should also be performed as well as a parsing of the risk of an incorrect decision for individual and collective health (WHO, 2006; Cook, Addicks, Wu, 2008).

The quantity of excipients in the IR product should be consistent with their intended function. Large quantities of certain excipients, such as surfactants (e.g., sodium laurylsulfate) or osmotic ingredients (e.g., sorbitol) may be problematic and should be avoided except when present in the reference drug (United States, 2000).
Since 1977 , WHO has periodically prepared a list of essential medicines for basic health care. Two studies, one conducted by Kasim and colleagues, in 2004, and the other held by Lindenberg, Kopp, Dressman, in 2004, provisionally classified by the $\mathrm{BCS}$, drugs presented at the 12th edition of this list (2002). The results of these studies have been compiled and presented in Figure 1.

In 2006, Takagi and colleagues (2006) also classified by the BCS the 200 best-selling drugs in the United States, Spain, Britain and Japan. In short, over 55\% of these drugs were classified as highly soluble (class I and III), and approximately $30 \%$ of all drugs contained in oral solid dosage forms may be classified as highly soluble and highly permeable (Class I).

One of the main initiatives of the FDA regarding biowaiver based on BCS was to form a Technical Committee to review the requests of biowaiver in March of 2004. This committee met six times between 2004 to 2006 and evaluated 25 requests of biowaiver, 11 for new molecules and 14 for generics. Of the 11 requests for new molecules analyzed, 7 of them were for drugs of class I and had biowaiver accepted. Of the 14 requests for generics biowaiver, 9 drugs belonged to class I. Of these, four were accepted (Polli et al., 2008).

Biowaiver requests based on BCS were also analyzed by EMA, and the following have been accepted for biowaiver: phenoxymethylpenicillin, prednisolone, transexamico acid, acetaminophen, codeine and ibuprofen in Sweden (Graffner, 2006), and sotalol hydrochloride in Germany (Alt et al., 2004).

A new approach to ensure a safe decision about biowaiver initiated in 2004 , by the International Pharmaceutical Federation (FIP) that has published a number of monographs containing relevant data available on literary sources for a given drug. These monographs are intended to support the discussion of risk associated with biowaiver of certain drugs selected by a group of experts from the FIP included in List of Essential Drugs. For this proposal, risk is defined as the probability of an incorrect biowaiver decision, as well as their consequences in terms of public health and risk to patients. This initiative has the support of WHO and aims especially to assist developing countries, in the approval and registration of generic medicines through biowaiver (FIP).

In these monographs, a recommendation was made about the possibility to biowaiver and although they do not have formal regulatory status, represent the best currently available scientific opinion. Until 2009, approximately 26 drugs have been evaluated in these monographs and the exemption of in vivo BE was scientifically justified 
TABLE II - Main requirements for obtaining biowaiver based on BCS

\begin{tabular}{|c|c|c|c|c|}
\hline & \multicolumn{4}{|c|}{ REGULATORYAGENCY } \\
\hline & FDA & ANVISA & EMA & OMS \\
\hline $\begin{array}{l}\text { Candidates according to } \\
\text { BCS }\end{array}$ & \multicolumn{2}{|c|}{ Class I } & Class I and III** & Class I, II* e III** \\
\hline $\begin{array}{l}\text { Characteristic for high } \\
\text { solubility classification } \\
\text { of drugs }\end{array}$ & $\begin{array}{l}\text { Higher dose commercially } \\
\text { available must be soluble } \\
\text { in } \leq 250 \mathrm{~mL}, \mathrm{pH} 1-7.5, \\
37^{\circ} \mathrm{C}\end{array}$ & \multicolumn{3}{|c|}{$\begin{array}{l}\text { Highest single dose administered to the patient and provided in package } \\
\text { insert must be soluble in } \leq 250 \mathrm{~mL}, \mathrm{pH} 1.2 \text { to } 6.8,37^{\circ} \mathrm{C} \text {. }\end{array}$} \\
\hline $\begin{array}{l}\text { Classification of high } \\
\text { permeability drugs }\end{array}$ & \begin{tabular}{|c|} 
Superior to metoprolol \\
absorption (absorption $\geq 90$ \\
$\%$ of administered dose)
\end{tabular} & \multicolumn{3}{|c|}{ Absorption $\geq 85 \%$} \\
\hline Dissolution media & \multicolumn{4}{|c|}{ buffer pH1.2, 4.5 and $6.8 ; 37^{\circ} \mathrm{C}$} \\
\hline Volume of medium & \multicolumn{2}{|c|}{$900 \mathrm{~mL}$} & $500 \mathrm{~mL}$ & $900 \mathrm{~mL}$ \\
\hline Apparatus and rotation & \multicolumn{3}{|c|}{ Paddle: 50 rpm/Basket: 100 rpm. } & $\begin{array}{l}\text { Paddle: } 75 \mathrm{rpm} / \\
\text { Basket: } 100 \mathrm{rpm} . \\
\end{array}$ \\
\hline Dissolution profile & \multicolumn{2}{|c|}{ I:Rapid dissolving } & $\begin{array}{l}\text { I: Rapid dissolving } \\
\text { III: Very rapid } \\
\text { dissolving }\end{array}$ & $\begin{array}{l}\text { I: Rapid dissolving } \\
\text { II: Rapid dissolving } \\
\text { at pH 6,8 } \\
\text { III: Very rapid } \\
\text { dissolving }\end{array}$ \\
\hline $\begin{array}{l}\text { Recommendations about } \\
\text { the excipient }\end{array}$ & $\begin{array}{l}\text { Excipients used in } \\
\text { the dosage form must } \\
\text { have been used in a } \\
\text { previously approved } \\
\text { immediate release (IR) } \\
\text { solid oral dosage form } \\
\text { by the Food and Drug } \\
\text { Administration. }\end{array}$ & $\begin{array}{l}\text { Qualitatively the same } \\
\text { and quantitatively very } \\
\text { similar to the respective } \\
\text { reference drug product }\end{array}$ & $\begin{array}{c}\text { Absence of excipients } \\
\text { that have an impact on } \\
\text { bioavailability. }\end{array}$ & \\
\hline
\end{tabular}

* Weak acid, high solubility in $\mathrm{pH} 6,8$, rapid or very rapid dissolving. ** Very rapid dissolving ( $85 \%$ in 15 minutes)

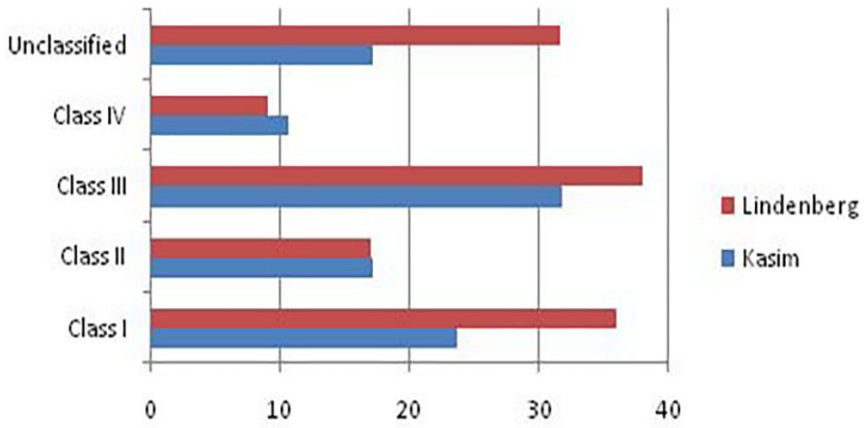

FIGURE 1 - Provisional Classification of drugs present in the $12^{\text {th }}$ edition of the essential drugs list proposed by Kasim et al. (2004) and Lindenberg, Kopp, Dressman (2004).

and recommended for the vast majority of them. These monographs are part of an ongoing project, and the details and progress of this plan are available in www.fip. org/bcs (Dahan et al., 2009). So far, in 2014, around 40 monographs dealing with drugs have been written.
Although there was an increase in the number of applications of biowaiver based on BCS, this progress has been tempered by the lack of international harmonization and the reluctance of companies to adhere to the methodology due to fears raised by a possible delay in the registers. Future progress in the use of biopharmaceutical in vitro data to substitute in vivo data by bioequivalence can also lead to benefits to achieve greater certainty in regulatory decisions, e.g. more scientific opportunities to discuss the necessary data and successful examples (Polli et al., 2008).

As previously mentioned, approximately $30 \%$ of all drugs contained in oral solid dosage forms may be classified as highly soluble and highly permeable (Takagi et al., 2006). So it may be surprising that, between 2003 and 2006, only 25 requests (11 for new drugs and 14 for generics) were submitted to the FDA for exemption from an in vitro study based on biopharmaceutical classification. The perceived lack of certainty of the acceptance by

\section{BIOWAIVER PETITIONS BASED ON BCS}


regulatory agencies of biowaiver requests based on BCS has been cited as one reason for the small number of requests by pharmaceutical industry (Polli et al., 2008).

Despite agencies like the FDA undertake significant efforts to promote the use of biowaiver based BCS, the time between the submission of an application for biowaiver and the formal approval needs to be fast enough (e.g., within weeks instead months), to have the adhesion of pharmaceutical companies. Not granting the biowaiver approval can lead to a significant delay in the development program of a new pharmaceutical product. Initially, the risk associated with receiving a negative response from biowaiver seemed greater than the benefits of economy of resources (Cook, Addicks, Wu, 2008). Nowadays, greater disclosure procedures for testing solubility and permeability as well as the expansion and dissemination of studies of drugs that could be waiver of bioequivalence studies contributes to expanding the adherence of the pharmaceutical industry (ANVISA, 2013; Cristofoletti et al., 2013).

Another barrier to the application of biowaiver refers to compartmentalization of some large companies, which can cause doubt as to the allocation of financial resources and the allocation of responsibilities regarding the success or failure of the biowaiver request. In the first case, the values saved by an organization resulting from a biowaiver typically appear in the clinical department budget. However, departments such as preclinical pharmacokinetic, chemistry and formulation may be required to perform more than the normal amount of work to support the application of a biowaiver. As a result, there may be reluctance by all parts of the organization to support a strategy for biowaiver. In the second case, the difficulty to employ biowaiver based on BCS can also be caused by lack of clarity on the responsibility to generate documents for biowaiver and to the attribution of blame, if a request of biowaiver is rejected and the time to launch a new product is delayed (Cook, Addicks, Wu, 2008).

\section{DISCUSSION}

The BCS developed by Amidon et al. (1995) aimed to employ specific tests in vitro in order to predict the drugs dissolution and therefore to estimate the results of their bioavailability (BD) in vivo, produced a significant impact on drug policy, making it possible to exempt $\mathrm{BD}$ and $\mathrm{BE}$ tests in vivo for class I drugs in oral solid dosage forms (FDA, EMA, ANVISA and WHO) for class III (EMA and WHO) and for a specific group of class II compounds (WHO). This is highly relevant for the possible decrease in the costs for registration of new generic drugs (Ramirez et al., 2010).

However, as shown in Figure 1, there are drugs in the WHO essential drugs list that have not been classified according to the BCS. This is because of the difficulty in obtaining permeability data, determined in vivo by absolute bioavailability or using in vitro, in silico and ex vivo models. Although for the registration of new drugs is necessary to define the absolute bioavailability, this is not usually easily accessible. As regards the other applicable models difficulties of standardization of methodologies, reproducibility of results and inconsistency with in vivo data are observed (Souza, Freitas, Storpirtis, 2007).

There are some criticisms of the use of BCS that fail in taking into account the dynamic system that occurs in vivo. An example of this is non-steroidal anti-inflammatory drugs that are classified as II and show extensive absorption. The biopharmaceutics drug disposition classification system (BDDCS), an alternative to the BCS, was proposed by Benet and collaborators (2008). It classifies drugs using aqueous solubility and metabolism (for the classification of permeability). This system aims to explain the results of $\mathrm{BD}$ in vivo for drugs with high permeability and also extensive metabolism. The correlation between metabolism and permeability can be explained in the case of drugs BCS of class I and II (highly permeable) that are able to reach the metabolic enzymes in hepatocytes. On the other hand, there are also limitations to BDDCS, among which the need of a suitable methodology that is able to predict the effect of the formulation components on the intestinal transporters. An example of the discrepancy of the results is sotalol, which has low liver metabolism, absorption less than $90 \%$, and is approved by the FDA as Class I (Benet et al., 2008; Chen, Yu, 2009).

The same occurs to solubility data, although available in greater number in the literature, were not always obtained from experiments performed in accordance to biowaiver requirements as the means and temperature appropriate (Table I) (Lindenberg, Kopp, Dressman, 2004).

Furthermore, the BCS must be selectively used and considering carefully regulatory risks versus the benefits for a possible biowaiver. In particular, for compounds that do not have clarity on permeability data from the literature, the potential risk of rejection of the permeability study submitted or a potential delay due to issues that may arise during the review of the data, must be weighed against time and costs required to conduct a bioequivalence study (Cook, Addicks, Wu, 2008). It should also be demonstrated that the excipients included in the new formulation are well established for use in products containing such drug. These 
pharmaceutical adjuvants should not cause differences between the reference product and the generic candidate product in in the terms of affecting the absorption process, or other pharmacokinetic processes (WHO, 2006).

Noteworthy, the demonstration of bioequivalence is the biggest concern for the approval and use of generic products, and the possibility of a biowaiver for in vivo bioequivalence studies must be approached with caution and careful supervision to ensure the safety and efficacy of these drugs (Ramirez et al., 2010).

In practice, a universalization of the benefits of biowaiver based on BCS is not expected due to the existence of differences in regulations worldwide. For example, while the United States (FDA, 2000), the European Union (EMEA, 2008), Brazil (Brasil, 2011) and WHO (2006) allow biowaiver based on dissolution and classification by BCS, Japan does not allow it (Yamashita, Tachiki, 2008). At this point, the FDA's and EMA's guide and the proposed requirements by WHO for biowaiver also show discrepancies in the definitions of high solubility ( $\mathrm{pH}$ of 7.5 in the FDA's guide and 6.8 in EMA's guide and WHO proposal) and high permeability (the criterion of $90 \%$ on FDA's guide and $85 \%$ in the WHO proposal and EMA's guide) (Ramirez et al., 2010). Consequently, this leads to global pharmaceutical companies choosing to demonstrate the bioequivalence using a methodology that will enable acceptance by most countries. In general, there is a historical reluctance of these companies in continuing with biowaiver based on BCS due to uncertainty as to the success in their petitions to the various regulatory agencies (Cook et al., 2010).

The new drugs biowaiver employing the criterion of the BCS, according to Brazilian and U.S. regulations is indicated for solid oral dosage forms of immediate release, whose drugs are Class I (Brasil, 2011). It is also desirable that they are stable in the gastrointestinal tract, have wide therapeutic range, are not absorbed in the oral cavity, present low risk, their formulations contain excipients that do not significantly affect the rate and extent of oral absorption. Drugs are considered low-risk are the ones for which there are no reports of bioavailability or bioequivalence problems (United States, 2000).

According to the guidelines of WHO and EMA, Class III drugs can be included in the list of candidates for biowaiver. For this class, permeability is the factor that controls the absorption, so care should be taken since the rate and extent of absorption can be highly variable. The dissolution profile of the formulation should be clearly defined and reproducible (EMEA, 2008; WHO, 2006; Tsume, Amidon, 2010; Reddy, Karunakar, 2011).

For WHO, class II drugs are also likely biowaivers if they are weak acids showing high solubility at $\mathrm{pH} 6.8$ and present, rapid or very rapid dissolving. For this class the limiting step of absorption is dissolution in vivo, thus the dissolution profile should be clearly defined and reproducible, emphasizing the importance of using methods that reflect or control the dissolution process in vivo (WHO, 2006; Alvarez et al., 2011).

Cristofoletti and colleagues (2013) calculated the diagnostic indicators utilizing 22 results of in vitro dissolution profiles performed at neutral conditions (phosphate buffer under $\mathrm{pH}$ 6.8-7.5) for a set of eight non$\mathrm{BE}$ (all of them because of Cmax) and $14 \mathrm{BE}$ drug products containing five weak acidic drugs, with $\mathrm{pKa}$ of less than 5.5 and which have dose numbers lower than one at $\mathrm{pH}$ values ranging from 6.8 to 7.4 . However, these diagnostic parameters not were different from those calculated for all drugs belonging to BCS class II, in accordance with the previous reports for drug products containing ibuprofen that showed that dissolution tests, under neutral conditions, were unable to detect differences in absorption rate.

To minimize the risk of an incorrect decision about biowaiver in terms of public health and of individual risks to patients, the therapeutic indications of the drug, its pharmacokinetic variations, interactions with food, and other factors, should be evaluated (Mehta, 2007).

Exceptionally, excipients can have an impact on in vivo permeability, either directly in the active or passive passage of the drug through the gut wall or indirectly by altering the gastrointestinal transit time/residence time. The possible appearance of these effects is a risk that should not be ignored, but are relatively rare, and tend to require many specific high risk excipients to cause significant change in vivo (Butler, Dressman, 2010). It should be emphasized that a description of excipients is required, with a justification if the amount of each excipient is within the range considered normal. The so called active excipients such as, for example, sorbitol, mannitol, sodium lauryl sulfate or other surfactant must be identified when present in the medicine as well as their possible impact with respect to: gastrointestinal motility, sensitivity interaction with the drug, the drug permeability and interaction with membrane transporters. In those cases where critical excipients are relevant, the same amount should be used in both reference and generic products (EMEA, 2008).

\section{CONCLUSION}

One of the current applications of BCS is to supply means to provide biowaiver of new generic medicines containing drugs belonging to Class I (FDA, EMA, WHO and ANVISA), class III (EMA and WHO) and a 
specific group of compounds of class II (WHO). Granting of biowaiver based on criteria such as BCS eliminates unnecessary exposure of healthy individuals to drugs, reduces the regulatory burden, and provides economic relief, maintaining the high standard of public health for therapeutic equivalence (Cook et al., 2010). Especially in developing countries, where there are often insufficient resources to achieve the bioequivalence studies, the use of BCS becomes an important tool to ensure the efficiency and quality of pharmaceutical products (Benet et al., 2008).

In this article, it was found that the BCS, greatly expands the possibilities of biowaiver, contributing to give greater flexibility to the registration of generic medicines of assured efficacy and safety, thus providing increased supply of affordable treatment options, which meets the public policy expanding access to medicines to the population. Since the politic of generics was deployed in Brazil, in 1999, a huge amount of investment has been made in order to inform people that the generic products pass by bioequivalence test and they are as effectives and safe as the reference drug. In 2014, it was proposed that similar drugs are interchangeable with the reference drugs. According to the proposal, similar packaging hall include in its brand, "equivalent product", symbolized by the acronym "EQ". The brand will enable consumers and physicians to identify products that have proof of equivalence and perform the same therapeutic function in relation to the reference (ANVISA, 2014). Therefore, it should be emphasized that a safe biowaiver decision should be made scientifically based on adequate and reliable experimental data, aiming not to put this politics into disrepute.

\section{ACKNOWLEDGMENTS}

This work was supported by PROPP/UFOP, Capes, FAPEMIG (APQ-00481_11 and Toxifar Network), and Anvisa (TC 007/2012).

\section{REFERENCES}

AGÊNCIA NACIONAL DE VIGILÂNCIA SANITÁRIA. ANVISA. Instrução Normativa - IN N ${ }^{0} 2$, de 14 de março de 2013. "Dispõe sobre a lista de fármacos candidatos à bioisenção baseada no sistema de classificação biofarmacêutica (SCB) e dá outras providências". Available at: $<$ http://bvsms.saude.gov.br/bvs/saudelegis/anvisa/2013/ int0002_14_03_2013.html>.
A GÊNCIA NACIONAL DE VIGILÂNCIA SANITÁRIA. ANVISA. Consulta Pública $-\mathrm{N}^{0} 1$, de 2014. "Dispõe sobre medicamentos equivalentes". Available at: $<$ http://portal.anvisa.gov.br/wps/wcm/ connect/20ddca8042979c349ae8db1bb0036de1/ Conuslta $+\mathrm{P} \% \mathrm{C} 3 \%$ BAblica $+\mathrm{n} \% \mathrm{C} 2 \% \mathrm{~B} 0++1+\mathrm{DIMON}+$. pdf?MOD=AJPERES $>$. Accessed on: Sept. 2013.

ALT, A.; POTTHAST, H.; MOESSINGER, J.; SICKMÜLLER, B.; OESER, H. Biopharmaceutical characterization of sotalol-containing oral immediate release drug products. Eur. J. Pharm. Biopharm., v.58, n.1, p.145-150, 2004.

ALVAREZ, C., NUNEZ, I., TORRADO, J. J., GORDON, J., POTTHAST, H., GARCIA-ARIETA, A. Investigation on the possibility of biowaivers for ibuprofen. J. Pharm. Sci., v.100, n.6, p.2343-2349, 2011.

AMIDON, G. L.; LENNERNÄS, H.; SHAH, V. P.; CRISON, J. R. A theoretical basis for a bio-pharmaceutical drug classification: the correlation of in vitro drug product dissolution and in vivo bioavailability. Pharm. Res., v.12, n.3, p.413-420, 1995.

ARAÚJO, L. U.; ALBUQUERQUE, K. T.; KATO, K. C.; SILVEIRA, G. S.; MACIEL, N. R.; SPÓSITO, P. A.; SILVA-BARCELLOS, N. M.; SOUZA, J.; BUENO, M.; STORPIRTIS, S. Medicamentos genéricos no Brasil: panorama histórico e legislação. Rev. Panam. Salud Publica, v.28, n.6, p.480-492, 2010.

BALIMANE, P. V.; CHONG, S.; MORRISON, R. A. Current methodologies used for evaluation of intestinal permeability and absorption. J. Pharmacol. Toxicol. Methods, v.44, p.301-312, 2000.

BENET, L; AMIDON, G .L.; BARENDS, D.; LENNERNÄS, H.; POLLI, J.; SHAH, V.; STAVCHANSKY, S.; YU, L. The use of BDDCS in classifying the permeability of marketed drugs. Pharm. Res., v.52, p.483-488, 2008.

BRASIL. Resolução RDC n ${ }^{\circ} 135$ de 29 de maio de 2003 a. "Regulamento técnico para medicamentos genéricos". Available at: <http://www.anvisa.gov.br/legis/resol/2003/ rdc/135_03rdc.htm>. Accessed on: 15 Mai. 2012.

BRASIL. Resolução RDC n 134 de 29 de maio de $2003 b$. "Dispõe sobre a adequação dos medicamentos já registrados". Available at: <http://www.anvisa.gov.br/ legis/resol/2003/rdc/134_03rdc.htm>. Accessed on: 15 Mai. 2012. 
BRASIL. Objetivos de Desenvolvimento do Milênio. 2007. Available at: <http://www.ipea.gov.br/sites/000/2/ download/TerceiroRelatorioNacionalODM.pdf $>$. Accessed on: 12 Jun. 2012.

BRASIL. Resolução RDC no 31 de 11 de agosto de 2010. "Dispõe sobre a realização dos Estudos de Equivalência Farmacêutica e de Perfil de Dissolução Comparativo." Available at: <http://bvsms.saude.gov.br/bvs/saudelegis/ anvisa/2010/res0031_11_08_2010.html>. Accessed on: 15 May 2012.

BRASIL. Resolução RDC no 37 de 3 de agosto de 2011. "Guia para isenção e substituição de estudos de biodisponibilidade relativa/bioequivalência" Available at: $<$ http://bvsms.saude. gov.br/bvs/saudelegis/anvisa/2011/res0037_03_08_2011. html>. Accessed on: 15 May 2012.

BUTLER, J. M.; DRESSMAN, J. B. The develop ability classification system: Application of biopharmaceutics concepts to formulation development. J. Pharm. Sci., v.99, n.12, p.4940-4954, 2010.

CHEN, M. L; YU, L. The use of drug metabolism for prediction of intestinal permeability. Mol. Pharm.,v.6, n.1, p.74-81, 2009.

COOK, J. A.; ADDICKS, W.; WU, Y. H. Application of the biopharmaceutical classification system in clinical drug development - an industrial view. AAPS, v.10, n.2, p.306$310,2008$.

COOK, J. A.; DAVIT, B. M.; POLLI, J. E. Impact of Biopharmaceutics Classification System-Based Biowaivers. Mol. Pharm., v.7, n.5, p.1539-1544, 2010.

CRISTOFOLETTI, R., CHIANN, C., DRESSMAN, J., STORPIRTIS, S. A Comparative Analysis of Biopharmaceutics Classification system and biopharmaceutics drug disposition classfication system: a Cross-Sectional Survey with 500 bioequivalence studies. J. Pharm. Sci., v.102, n.9, p. 3136-3144, 2013.

DAHAN, A.; MILLER, J. M; AMIDON, G. L. Prediction of Solubility and Permeability Class Membership: Provisional BCS Classification of the World's Top Oral Drugs. AAPS, v.11, n.4, p.740-746, 2009.
EMEA. European Agency for Evaluation of Medicinal Products, Committee for Proprietary Medicinal Products. Note for Guidance on the Investigation of Bioavailability and Bioequivalence. 2001. Available at: <http://www.ema. europa.eu/pdfs/human/qwp/140198enfin.pdf $>$. Accessed on: 23 Abr. 2011.

EMEA. European Medicines Agency, Committee for Medicinal Products for Human Use (CHMP). Guideline on the Investigation of Bioequivalence. 2008. Available at: $<$ http:// www.ema.europa.eu/pdfs/human/qwp/140198enrev1.pdf>. Accessed on: 30 Mai. 2012.

INTERNATIONAL PHARMACEUTICAL FEDERATION. FIP. Available at: $<$ http://www.fip.org/bcs $>$. Accessed on: 4 Mai. 2012. [site].

GRAFFNER, C. Regulatory aspects of drug dissolution from a European perspective. Eur J. Pharm. Sci., v.29, n.3-4, p.288-293, 2006.

KASIM, N. A.; WHITEHOUSE, M.; RAMACHANDRAN, C.; BERMEJO, M.; LENNERNÄS, H.; HUSSAIN, A. S.; JUNGINGER, H. E.; STAVCHANSKY, S. A.; MIDHA, K. K.; SHAH, V. P.; AMIDON, G. L. Molecular properties of WHO essential drugs and provisional Biopharmaceutical Classification. Mol. Pharm., v.1, n.1, p.85-96, 2004.

LEACH, B.; PALLUZI, J. E.; MUNDERI, P. Prescription for healthy development: increasing access to medicines. London: United Nations Development Programme, 2005. Available at: $<$ http://www.unmillenniumproject.org/reports/ tf_essentialmedecines.htm>. Accessed on: 27 May 2012.

LENNERNÄS, H.; ABRAHAMSSON, B. The use of biopharmaceutic classification of drugs in drug discovery and development: current status and future extension. $J$. Pharm. Pharmacol., v.57, n.3, p.273-285, 2005.

LINDENBERG, M.; KOPP, S.; DRESSMAN, J. B. Classification of orally administered drugs on the World Health Organization Model list of Essential Medicines according to the biopharmaceutics classification system. Eur. J. Pharm. Biopharm., v.58, n.2, p.265-278, 2004.

LÖBENBERG, R.; AMIDON, G. L. Modern bioavailability, bioequivalence and biopharmaceutics classification system. New scientific approaches to international regulatory standards. Eur. J. Pharm. Biopharm., v.50, n.1, p.3-12, 2000 . 
MANADAS, R.; PINA, M. E.; VEIGA, F. A dissolução in vitro na previsão da absorção oral de fármacos em formas farmacêuticas de liberação modificada. Rev. Bras. Cienc. Farm., v.38, n.4, p.375-399, 2002.

MARTINEZ, M. N.; AMIDON, G. L. A Mechanistic approach to understanding the factors affecting drug absorption: a review of fundamentals. J. Clin. Pharmacol., v.42, p.620$643,2002$.

MELO, M. G. M. A produção de medicamentos genéricos no Brasil: Dificuldades e perspectivas. Porto Alegre, 2005. 164p. [Dissertação de Mestrado. Faculdade de Farmácia. Universidade Federal do Rio Grande do Sul].

MEHTA, M. FDA Regulatory use of BCS. In: AAPS workshop on BE, BCS, and beyond, 2007, North Bethesda, MD. p.21-23. Available at: http://www.aapspharmaceutica.com/ meetings/files/90/04Mehta.pdf. Accessed on: may. 2011.

MIRANDA, E. S.; PINTO, C. B. S.; REIS, A. L. A.; EMMERICK, I. C. M.; CAMPOS, M. R.; LUIZA, V. L., OSORIO-DE-CASTRO, C. G. S. Disponibilidade no setor público e preços no setor privado: um perfil de medicamentos genéricos em diferentes regiões do Brasil. Cad. Saúde Pública, v.25, n.10, p.2147-2158, 2009.

PANCHAGNULA, R.; THOMAS, N. S. Biopharmaceutics and pharmacokinetics in drug research. Int. J. Pharm., v.201, n.2, p.131-150, 2000.

POLLI, J. E.; ABRAHAMSSON, B. S. I, YU, L. X.; AMIDON, G. L.; BALDONI, J. M.; COOK, J. A.; FACKLER, P.; HARTAUER, K.; JOHNSTON, G.; KRILL, S. L.; LIPPER, R. A.; MALICK, W. A.; SHAH, V. P.; SUN, D.; WINKLE, H. N.; WU, Y.; ZHANG, H. Summary Workshop Report: Bioequivalence, Biopharmaceutics Classification System, and Beyond. AAPS, v.10, n.2, p.373-379, 2008.

RAMIREZ, E.; LAOSA, O.; GUERRA, P.; DUQUE, B.; MOSQUERA, B.; BOROBIA, A. M.; LEI, S. H.; CARCAS, A. J.; FRIAS, J. Acceptability and characteristics of 124 human bioequivalence studies with active substances classified according to the Biopharmaceutic Classification System. Br. J. Clin. Pharmacol., v.70, n.5, p.694-702, 2010.

REDDY, B. B. K.; KARUNAKAR, A. Biopharmaceutics Classification System: a regulatory approach. Dissol. Technol., v.2, p.31-37, 2011.
RODRIGUES, P. O.; STULZER, H. K.; CRUZ, A. P.; FOPPA, T.; CARDOSO, T. M.; SILVA, M. A. S. Equivalência Farmacêutica entre Comprimidos de propranolol Comercializados no Mercado Nacional. Infarma, v.18, n.3-4, p.16-21, 2006.

SOUZA, J.; FREITAS, Z. M. F.; STORPIRTIS, S. Modelos in vitro para determinação da absorção de fármacos e previsão da relação dissolução/absorção. Rev. Bras. Cienc. Farm., v.43, n.2, p.1-13, 2007.

STORPIRTIS, S.; CONSIGLIERI, V. O. Biodisponibilidade e bioequivalência de medicamentos: aspectos fundamentais para o planejamento e execução de estudos. ver. Farm. Bioquim. Univ. São Paulo, v.31, n.2, p.63-70, 1995.

STORPIRTIS, S.; OLIVEIRA, P. G.; RODRIGUES, D.; MARANHÃO, D. Considerações biofarmacotécnicas relevantes na fabricação de medicamentos genéricos: fatores que afetam a dissolução e a absorção de fármacos. Rev. Bras. Cienc. Farm., v.35, n.1, p.1-16, 1999.

STORPIRTIS, S.; MARCOLONGO, R.; GASPAROTTO, F.S.; VILANOVA, C.M. A equivalência farmacêutica no contexto da intercambialidade entre medicamentos genéricos e de referência: bases técnicas e científicas. Brasília: ANVISA; 2004. Available at: <http://www.anvisa.gov.br/divulga/ artigos/index.htm>. Accessed on: 01 August 2011.

STORPIRTIS, S.; GAI, M. N. Biofarmacotécnica: princípios de biodisponibilidade, bioequivalência, equivalência farmacêutica, equivalência terapêutica e Intercambialidade de medicamentos. In: STORPIRTIS, S.; GONÇALEZ, J. E.; CHIANN, C.; GAI, M. N. (Eds.). Biofarmacotécnica. 1.ed. Rio de Janeiro: Guanabara Koogan, 2009. p.3-11.

TAKAGI, T.; RAMACHANDRAN, C.; BERMEJO, M.; YAMASHITA, S.; YU, L. X.; AMIDON, G. L. A Provisional Biopharmaceutical Classification of the Top 200 Oral Drug Products in the United States, Great Britain, Spain, and Japan. Mol. Pharm., v.3, n.6, p.631-643, 2006.

TSUME Y., AMIDON G. L. The biowaiver extension for BCS class III drugs: The effect of dissolution rate on the bioequivalence of BCS class III immediate-release drugs predicted by computer simulation. Mol. Pharm., v.7, n.4, p.1235-1243, 2010. 
UNITED STATES. U. S. Department of Health and Human Services, Food and Drug Administration. Center of Drug Evaluation and Research (CDER). Guidance for Industry. Dissolution Testing of Intermediate Release Solid Oral Dosage Forms, Rockville: FDA. 1997. Available at: $<$ http:// www.fda.gov/downloads/Drugs/GuidanceComplianceReg ulatoryInformation/Guidances/ucm070237.pdf > . Accessed on: 25 May 2012.

UNITED STATES. U. S. Department of Health and Human Services, Food and Drug Administration. Center of Drug Evaluation and Research (CDER). Guidance for Industry: Waiver of In Vivo Bioavailability and Bioequivalence Studies for Immediate-Release Solid Oral Dosage Forms Based on a Biopharmaceutics Classification System, Rockville: FDA. 2000. Available at: <http://www.fda. gov/downloads/Drugs/GuidanceComplianceRegulatoryIn formation/Guidances/ucm070246.pdf>. Accessed on: 25 May 2012.

UNITED STATES, U. S. Department of Health and Human Services, Food and Drug Administration. Statement of Andrew C. von Eschenbach, M.D. Commissioner of the Food and Drug Administration 2007. Available at: <http:// www.fda.gov/NewsEvents/Testimony/ucm154237.htm>. Accessed on: 02 Jun. 2012.
YAMASHITA, S.; TACHIKI, H. Analysis of risk factors in human bioequivalence study that incur bioinequivalence of oral drug products. Mol. Pharm., v.6, n.1, 48-59, 2008.

YU, L. X.; AMIDON, G. L.; POLLI, J. E.; ZHAO, H.; METHA, M. U.; CONNER, D. P.; SHAH, V. P.; LESKO, L. J.; CHEN, M. L.; LEE, V. H.; HUSSAIN, A. S. Biopharmaceutics Classification System: The scientific basis for biowaiver extensions. Pharm. Res., v.19, n.7, p.921-925, 2002.

WORLD HEALTH ORGANIZATION. WHO. The World Medicines Situation 2004. Available at: <http://apps.who. int/medicinedocs/en/d/Js6160e/>. Accessed on: 27 May 2012.

WORLD HEALTH ORGANIZATION. WHO. Proposal to waive in vivo bioequivalence requirements for WHO Model List of Essential Medicines immediate-release, solid oral dosage forms. Technical Report Series, No 937, 40 ${ }^{\text {th }}$ Report, Annex 8 of WHO Expert Committee on Specifications for Pharmaceutical Preparations. 2006. Available at: $<\mathrm{http}: / /$ whqlibdoc.who. int/trs/WHO_TRS_937_eng.pdf $>$. Accessed on: 5 March 2012.

Received for publication on $12^{\text {th }}$ September, 2013 Accepted for publication on $02^{\text {nd }}$ September 2014 